\title{
LIVER FUNCTION TESTS IN CHRONIC RELAPSING VIVAX MALARIA ${ }^{1}$
}

\author{
By STUART W. LIPPINCOTT, ${ }^{2}$ LESTER D. ELLERBROOK, ${ }^{3}$ WM. B. HESSELBROCK, ${ }^{3}$ \\ HARRY H. GORDON,4 LEO GOTTLIEB, ${ }^{4}$ AND ALEXANDER MARBLE 5.
}

(Received for publication March 7, 1945)

Hepatic function in chronic relapsing malaria caused by Plasmodium vivax and treated principally by atabrine has been investigated at Harmon General Hospital in 317 soldiers. This study seemed advisable because of previous reports that impairment of liver function may occur in both naturally-acquired ( 1 to 3 ) and induced malaria (4). Several types of tests were performed on our patients both during recurrent attacks and at various intervals afterwards. Most of these same tests were also performed on healthy individuals to determine whether in our laboratory the methods gave normal ranges of values corresponding to those found in the literature. This made it possible to compare the findings in our patients with those of our healthy control series, as well as with the results of other investigators.

The liver function tests used may be grouped roughly into 3 categories: (a) those in which hepatic dysfunction is suspected when abnormal values are found-bromsulfalein, cephalin flocculation, galactose tolerance and hippuric acid tests; (b) those in which an abnormal value may be associated with increased red blood cell destruction and/or hepatic dysfunction-icterus index, serum bilirubin concentration, and urine urobilinogen concentration; and (c) quantitative determinations of some constituents of blood serum occasionally found to yield abnormal results in persons with hepatic disease-albumin, globulin, total protein, cholesterol and phosphatase.

\section{METHODS}

1. Bromsulfalein (5): The amount of dye injected intravenously was $5 \mathrm{mgm}$. per $\mathrm{kgm}$. of body weight. The permanent standards used were supplied by Hynson, Westcott and Dunning. Since the standards were prepared for the $2 \mathrm{mgm}$. test, the calculations were made by dividing the readings obtained by 2.5 .

1 Patients studied were infected in South Pacific area.

2 Lieutenant Colonel, MC, A.U.S.

${ }^{8}$ Captain, $\mathrm{SnC}$, A.U.S.

4 Major, MC, A.U.S.

Colonel, MC, A.U.S.
2. Cephalin flocculation test $(6,7)$ : The cephalincholesterol antigens were obtained from the Difco Company (Digestive Ferments Company) of Detroit, Michigan, and from the Wilson Laboratories of Chicago, Illinois. The test was performed according to Hanger's method with the exception that most of the tests were kept in the dark since recently light has been reported as affecting the results (8).

3. Galactose tolerance test: Forty grams of galactose were given by mouth to fasting subjects. The amount of sugar excreted in the urine during the next 5 hours was determined by Benedict's quantitative method using a solution which had been standardized against galactose. The results were reported as galactose.

4. Intravenous hippuric acid test (9): Sodium benzoate (1.77 grams) was injected intravenously, and the urinary excretion of hippuric acid for a period of 1 hour was determined. The hippuric acid was salted out of the acidified urine with ammonium sulfate $(0.5$ gram per $\mathrm{ml}$.) at $20^{\circ} \mathrm{C}$. for 1 hour. The precipitate was filtered with suction and was washed with three $5 \mathrm{ml}$. portions of icecold water. In the calculation of the results, correction for the solubility of hippuric acid was made by adding 0.1 gram per $100 \mathrm{ml}$. of urine to the weight of precipitate obtained.

5. Icterus index: The color of the serum was compared with those of standard potassium dichromate solutions in $75 \times 12 \mathrm{~mm}$. test tubes. The serum was then diluted $1: 2$ and $1: 3$ with normal physiological saline, and the colors of these dilutions were matched with the standards as checks on the original value obtained. With an occasional serum, poor checks were obtained with the 2 dilutions, and in such a case the serum was diluted further until consistent values were obtained.

6. Serum bilirubin: The method used was the Thannhauser-Andersen modification (10) of the Van den Bergh test. The permanent cobalt sulfate standards of McNee and Keefer were used (11).

7. Urine urobilinogen: A modification of the Wallace and Diamond (12) serial dilution method was used on fresh morning specimens. The reagent was prepared by dissolving 0.15 gram paradimethylaminobenzaldehyde in $100 \mathrm{ml}$. of 20 per cent hydrochloric acid. Tests were routinely performed on a $1: 5$ dilution. Urine specimens yielding positive tests in this dilution were diluted further and tested again. The highest dilution in which a positive test was obtained was recorded.

8. Serum albumin and globulin: The method of Minot and Keller (13) was used.

9. Serum cholesterol: The method of Forbes (14) was used. 
10. Serum phosphatase: The method of Bodansky (15) was used. The final phosphorus determinations were made by the method of Fiske and Subbarow (16).

\section{RESULTS}

Bromsulfalein test: Control tests were run on 100 normal healthy subjects (Table I). At 45 minutes, 44 per cent of the individuals showed no retention of dyestuff, while 55 per cent showed

TABLE I

\begin{tabular}{|c|c|c|c|c|}
\hline \multicolumn{5}{|c|}{$\begin{array}{l}\text { Results of bromsulfalein tests at } 45 \text { minutes using } 5 \mathrm{mgm} \text {. per } \\
\text { kilogram body weight }\end{array}$} \\
\hline $\begin{array}{l}\text { Dye } \\
\text { retention }\end{array}$ & $\mid \begin{array}{c}100 \text { "Nor- } \\
\text { mal" controls }\end{array}$ & $\begin{array}{c}49 \text { Patients } \\
\text { on second } \\
\text { or third day } \\
\text { of attack }\end{array}$ & $\begin{array}{l}97 \text { Patients } \\
\text { on sixth or } \\
\text { seventh day } \\
\text { of attack }\end{array}$ & $\begin{array}{c}149 \text { Men } \\
\text { following } \\
\text { recurrent } \\
\text { attacks }\end{array}$ \\
\hline $\begin{array}{c}\text { per cent } \\
0 \\
2 \\
4 \\
6 \\
8 \\
10 \\
12\end{array}$ & $\begin{array}{c}\text { per cent } \\
44 \\
41 \\
14 \\
1\end{array}$ & $\begin{array}{c}\text { per cent } \\
53 \\
27 \\
16 \\
2 \\
2\end{array}$ & $\begin{array}{c}\text { per cent } \\
69 \\
29 \\
1 \\
\\
1\end{array}$ & $\begin{array}{c}\text { per cent } \\
60 \\
24 \\
13 \\
3\end{array}$ \\
\hline
\end{tabular}

2 or 4 per cent retention. One man, who was presumably a healthy individual, had 6 per cent retention. It was reported recently (17) that with $5 \mathrm{mgm}$. of dye, there.was no retention at 45 minutes, while others (5) accept up to 6 per cent retention at 60 minutes as normal. It was concluded that, under our conditions of testing, as much as 4 per cent retention at 45 minutes was to be considered normal.

During 49 recurrent attacks of malaria, the bromsulfalein test was done on the second or third day of the attack and repeated 3 or 4 days later. On the second and third days, 96 per cent of the results fell within the normal range. One man had 8 per cent retention and another had 12 per cent retention, but 3 or 4 days later both were normal. Ninety-seven patients (including the 49 who had been tested on the second or third day) were studied on the sixth or seventh day of an attack; the results were all normal at 45 minutes with the exception of that of 1 man in whom there was 10 per cent retention. Tests were performed on 149 men at intervals nf from 2 to 44 weeks after recurrent attacks of malaria. Of these men, 45 had had normal findings when previously tested from the second to the seventh days from the start of an attack and again showed normal results following attacks. Of the remaining 104 men, there were 4 who had 8 per cent retention at 45 minutes. Therefore, with reference to our control figures, only 4 per cent of the patients had abnormal values on the second or third days of an attack, 1 per cent on the sixth or seventh days of an attack, and 3 per cent after an attack. The total number of abnormal results by the bromsulfalein test, either during or after an attack was 7, or 2.4 per cent of 295 tests.

Cephalin flocculation test: Duplicate tests were performed with each serum using the Difco and Wilson antigens. Sera were obtained on the first 5 days during 42 recurrent attacks of malaria (Table II). With the Difco antigen, 82 per cent of the tests were positive, and each of the $42 \mathrm{pa}$ tients had at least 1 positive test during the 5-day period. With the Wilson antigen, 21 per cent of the tests were positive, and in only 50 per cent of the 42 patients was a positive test obtained during the 5 days.

TABLE II

Cephalin flocculation tests for five consecutive days during 42 recurrent attacks of malaria (comparing Difco and Wilson antigens on same sera)

Difco antigen

\begin{tabular}{l|r|r|r|r|r}
\hline \hline \multicolumn{1}{c|}{ Day } & \multicolumn{1}{c|}{0} & $1+$ & $2+$ & $3+$ & $4+$ \\
\hline First & 12 & 3 & 7 & 14 & 6 \\
Second & 6 & 4 & 8 & 10 & 14 \\
Third & 5 & 5 & 5 & 13 & 14 \\
Fourth & 8 & 6 & 8 & 8 & 12 \\
Fifth & 6 & 6 & 6 & 12 & 12 \\
\hline Total & 37 & 24 & 34 & 57 & 58 \\
\hline
\end{tabular}

Wilson antigen

\begin{tabular}{l|c|c|c|c|c}
\hline \multicolumn{1}{c|}{ Day } & 0 & $1+$ & $2+$ & $3+$ & $4+$ \\
\hline First & 38 & 1 & 0 & 2 & 1 \\
Second & 30 & 4 & 0 & 7 & 1 \\
Third & 33 & 2 & 1 & 5 & 1 \\
Fourth & 35 & 1 & 1 & 2 & 3 \\
Fifth & 30 & 1 & 3 & 5 & 3 \\
\hline Total & 166 & 9 & 5 & 21 & 9 \\
\hline
\end{tabular}

In duplicate tests on the sera of 204 men, 2 to 44 weeks following recurrent attacks of malaria, Table III shows that with the Difco antigen 20 per cent of the tests were positive, and with the Wilson antigen 5 per cent were positive. Each of the latter sera also gave positive results with the Difco antigen. Of the 41 men giving the positive tests with the Difco antigen, 24 were available for 
another test 5 weeks later without an intervening attack of malaria. At that time, tests of 10 of the sera were still positive. This group of 24 men included the 10 men who had given positive tests with the Wilson antigen and on re-testing 5 weeks later, without an intervening attack of malaria, only 2 remained positive.

TABLE III

Results of cephalin flocculation tests in 204 patients following recurrent attacks of malaria

\begin{tabular}{l|c|c|c|c|c}
\hline \multicolumn{1}{c|}{ Flocculation } & 0 & $1+$ & $2+$ & $3+$ & $4+$ \\
\hline Difco antigen & 163 & 4 & 8 & 16 & 13 \\
Wilson antigen & 194 & 0 & 0 & 7 & 3 \\
\hline
\end{tabular}

These results with duplicate tests, using the Difco and Wilson antigens, show that there is a substantial difference in the sensitivity of the two antigens. There is also a marked difference in results between the number of positive tests during the attacks and following the attacks when the results with the same antigen are compared. In spite of the difference in sensitivity between the 2 antigens, it is apparent that the disturbance producing the greater number of positive tests during attacks is of a transient character.

Galactose tolerance test: The galactose tolerance test was performed on 207 men from 4 to 52 weeks after an attack of malaria (Table IV). Only 7, or 3 per cent, of the men excreted over the accepted normal amount of 3 grams of galactose in 5 hours. The average excretion for the entire group at hourly intervals was as follows: first hour, 0.80 gram; second hour, 0.35 gram; third hour, 0.08 gram; fourth hour, 0.05 gram; and fifth hour, 0.02 gram.

TABLE IV

Galactose tolerance tests in 207 men following recurrent
attacks of malaria

$\begin{array}{cc}\text { Number in group } & \begin{array}{c}\text { Grams of galactose excreted } \\ \text { in five hours }\end{array} \\ 18 & 0.0 \\ 77 & 0.1-0.9 \\ 42 & 1.0-1.5 \\ 34 & 1.51-2.0 \\ 29 & 2.01-3.0 \\ 5 & 3.01-4.0 \\ 2 & 4.01-5.0\end{array}$

Intravenous hippuric acid test: The intravenous hippuric acid test using 1.77 grams of sodium benzoate was performed on 26 normal individuals and on 56 men following recurrent attacks of malaria (Table V). According to Quick (9), 1 gram or more of hippuric acid is excreted in 1 hour by a normal person. Certain workers (18) have pointed out that the amount of hippuric acid excreted bears a relationship to body weight. In their series of 46 normal individuals, they obtained values as low as 0.65 gram, and 9 per cent of their normal individuals excreted less than 0.90 gram. In our smaller series of 26 normals, 11 per cent excreted less than 0.90 gram. In our 56 men following attacks of malaria, 23 per cent excreted less than 0.90 gram.

TABLE V

Intravenous hippuric acid test (reported as hippuric acid)

\begin{tabular}{c|c|c|c|c|r}
\hline \hline \multicolumn{2}{c|}{$\begin{array}{c}\text { Normal healthy } \\
\text { controls }\end{array}$} & \multicolumn{3}{|c}{$56 \begin{array}{c}\text { Men following attacks } \\
\text { of malaria }\end{array}$} \\
\cline { 1 - 5 } \begin{tabular}{c|c|c|c|} 
Num- \\
ber
\end{tabular} & $\begin{array}{c}\text { Grams hip- } \\
\text { puric acid }\end{array}$ & $\begin{array}{c}\text { Per cent } \\
\text { of group }\end{array}$ & $\begin{array}{c}\text { Num- } \\
\text { ber }\end{array}$ & $\begin{array}{c}\text { Grams hip- } \\
\text { puric acid }\end{array}$ & $\begin{array}{c}\text { Per cent } \\
\text { of group }\end{array}$ \\
\hline 2 & $0.33-0.59$ & 7.7 & 2 & $0.33-0.59$ & 3.6 \\
1 & $0.60-0.79$ & 3.9 & 5 & $0.60-0.79$ & 8.9 \\
0 & $0.80-0.89$ & 0.0 & 6 & $0.80-0.89$ & 10.7 \\
3 & $0.90-0.99$ & 11.5 & 9 & $0.90-0.99$ & 16.1 \\
5 & $1.00-1.09$ & 19.3 & 10 & $1.00-1.09$ & 17.9 \\
6 & $1.10-1.19$ & 23.0 & 13 & $1.10-1.19$ & 23.2 \\
6 & $1.20-1.29$ & 23.0 & 5 & $1.20-1.29$ & 8.9 \\
3 & $1.30-1.58$ & 11.5 & 6 & $1.30-1.58$ & 10.7 \\
\hline
\end{tabular}

Icterus index and serum bilirubin concentration: It is customary to determine the icterus index and the bilirubin concentration of blood serum on fasting specimens. In our studies, most of the patients were having many specimens of blood taken for plasma atabrine determinations 2 to 4 hours after breakfast. In order to minimize the number of venepunctures, sera from these same specimens were used for the icterus index and bilirubin determinations. In doing this, it seemed essential that control values from non-fasting sera of healthy soldiers should be compared with the results in our patients, and in addition that the non-fasting specimens from healthy soldiers should be compared with fasting specimens to determine whether the results might be different. Sera were obtained from 562 normal healthy soldiers 2 to 4 hours after breakfast and, in addition, fasting sera from 115 of these men were obtained on the same day. Seven per cent of the fasting values for the icterus index were greater than 8 units, and 9 per cent of the fasting values for the serum bilirubin were greater than $0.50 \mathrm{mgm}$. per $100 \mathrm{ml}$. The results obtained with postprandial 
TABLE VI

Icterus index and serum bilirubin on the same postprandial sera of 562 normal healthy soldiers

\begin{tabular}{|c|c|c|c|c|c|c|c|}
\hline \multicolumn{4}{|c|}{ Icterus index } & \multicolumn{4}{|c|}{ Serum bilirubin } \\
\hline Units & 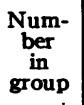 & $\begin{array}{l}\text { Per } \\
\text { cent }\end{array}$ & $\begin{array}{l}\text { Cumu- } \\
\text { lative } \\
\text { per } \\
\text { cent }\end{array}$ & $\begin{array}{l}\text { Mgm. } \\
\text { per 100 } \\
\text { ml. }\end{array}$ & $\underset{\substack{\text { ber } \\
\text { in } \\
\text { group }}}{\text { Num }}$ & $\begin{array}{l}\text { Per } \\
\text { cent }\end{array}$ & $\begin{array}{c}\text { Cumu- } \\
\text { lative } \\
\text { per } \\
\text { cent }\end{array}$ \\
\hline $\begin{array}{r}2 \\
3 \\
4 \\
5 \\
6 \\
7 \\
8 \\
9 \\
10 \\
11 \\
12 \\
13 \\
14\end{array}$ & $\begin{array}{r}2 \\
75 \\
114 \\
123 \\
115 \\
75 \\
26 \\
13 \\
5 \\
6 \\
3 \\
3 \\
1\end{array}$ & $\begin{array}{r}0.4 \\
13.4 \\
20.3 \\
21.9 \\
20.5 \\
13.4 \\
4.6 \\
2.3 \\
0.9 \\
1.1 \\
0.5 \\
0.5 \\
0.2\end{array}$ & $\begin{array}{r}0.4 \\
13.8 \\
34.1 \\
56.0 \\
76.5 \\
89.9 \\
94.5 \\
96.8 \\
97.7 \\
98.8 \\
99.3 \\
99.8 \\
99.9\end{array}$ & $\begin{array}{r}<0.10 \\
0.10 \\
0.15 \\
0.20 \\
0.25 \\
0.30 \\
0.35 \\
0.40 \\
0.45 \\
0.50 \\
0.55 \\
0.60 \\
0.65 \\
0.80 \\
0.85 \\
0.90 \\
1.00 \\
1.50\end{array}$ & $\begin{array}{r}183 \\
116 \\
86 \\
66 \\
31 \\
12 \\
14 \\
18 \\
9 \\
8 \\
5 \\
4 \\
1 \\
5 \\
1 \\
1 \\
1 \\
1\end{array}$ & $\begin{array}{r}32.6 \\
20.7 \\
15.3 \\
11.7 \\
5.5 \\
2.1 \\
2.5 \\
3.2 \\
1.6 \\
1.4 \\
0.9 \\
0.7 \\
0.2 \\
0.9 \\
0.2 \\
0.2 \\
0.2 \\
0.2\end{array}$ & \begin{tabular}{|r}
32.6 \\
53.3 \\
68.6 \\
80.3 \\
85.8 \\
87.9 \\
90.4 \\
93.6 \\
95.2 \\
96.6 \\
97.5 \\
98.2 \\
98.4 \\
99.3 \\
99.5 \\
99.7 \\
99.9 \\
100.1
\end{tabular} \\
\hline Total & 562 & & & Total & 562 & & \\
\hline
\end{tabular}

specimens tended to be slightly lower (Table VI). Five per cent of these values for the icterus index were greater than 8 units and 3 per cent of the values for serum bilirubin were greater than 0.50 mgm. per $100 \mathrm{ml}$.

During 108 attacks of malaria, both the icterus index and serum bilirubin concentration were determined on 5 successive days from the beginning of the attack. Following 118 attacks, the same tests were performed at intervals of 1,2 and 3 weeks after the attack. From the second to the fifteenth week after attacks, these same tests were performed on 997 specimens from 260 men. The results are shown in Figure 1. On the first day of the attack, 16 per cent of the values for the icterus index were greater than 8 units and 31 per cent greater than 7 units. By the fourth day, the percentage over 8 units had dropped to 1 per cent, a value smaller than the 5 per cent found in normal healthy soldiers. Similarly, the percentage greater than 7 units dropped to 3 per cent, whereas it was 10 per cent in the normal

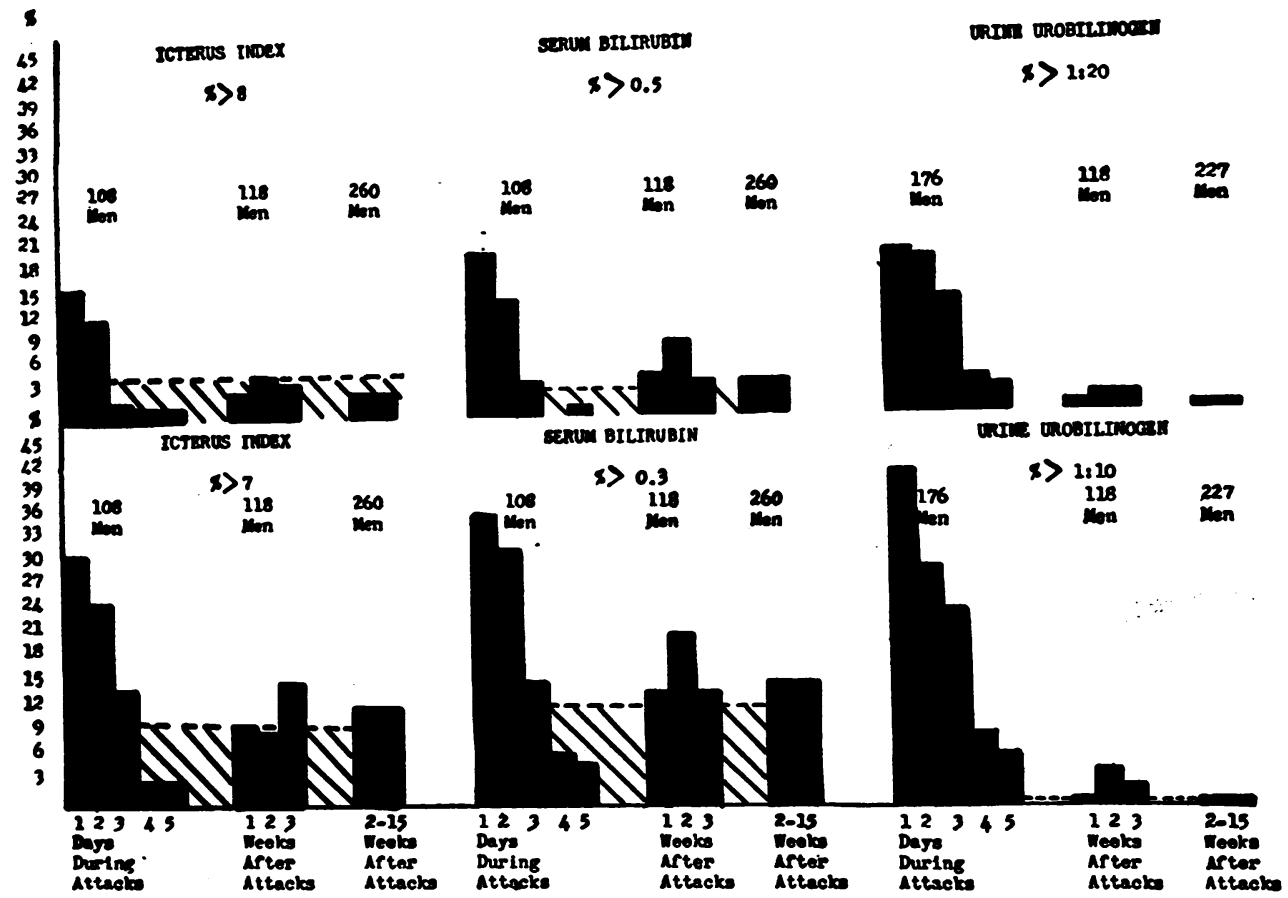

Fig. 1. Icterus Index, Serum Bilirubin, and Urine Urobilinogen During and After Recurrent Attacks of Malaria

(Compared with normal healthy men)

Keys: Solid blocks-patients with malaria 6,577 tests

Hatching-normal healthy controls 1,542 tests

Total tests $\overline{8,119}$ 
healthy soldiers. From 2 to 15 weeks after the attacks, the percentages greater than 8 and 7 units respectively were essentially the same as those encountered in the control group. Similar findings were observed with the serum bilirubin concentrations during the same periods. The increase in number of elevated values during the first part of the attack with subsequent fall to below normal and later elevation to about the normal level occurred with both tests. However, the degree of elevation was not great nor did it occur in every single indivdual.

Urine urobilinogen test: The test for urobilinogen was performed on fresh morning urine specimens of 960 individuals without malaria (Table VII). Of these, 418 were normal healthy soldiers. Only 3 per cent gave positive results in a maximum dilution of $1: 10$ and 1 per cent in a maximum dilution of $1: 20$. The remainder

TABLE VII

Urine urobilinogen on 960 individuals without malaria

\begin{tabular}{ccc} 
& Normal healthy men & \\
\cline { 2 - 2 } Dilution & Number & Per cent \\
$<1: 5$ & 281 & 67 \\
$1: 5$ & 122 & 29 \\
$1: 10$ & 11 & 3 \\
$1: 20$ & 4 & 1 \\
Total & 418 & 100 \\
\multicolumn{1}{c}{} & & \\
Dilution & General hospital patients & \\
\cline { 2 - 2 }$<1: 5$ & Number & Per cent \\
$1: 5$ & 324 & 73 \\
$1: 10$ & 108 & 25 \\
$1: 20$ & 7 & 2 \\
$1: 50$ & 2 & $<1$ \\
Total & 1 & $<1$ \\
& 442 & 100
\end{tabular}

of the group were 442 general hospital patients with no apparent liver damage. Only 2 per cent gave positive results at a dilution of $1: 10$. At a $1: 20$ dilution, 0.5 per cent were positive and a single individual with pneumonia was positive in a dilution of $1: 50$. These figures tend to show that in healthy men or in patients without apparent liver damage or obvious hemolysis, values above $1: 10$ are uncommon.

During 176 attacks of malaria, urine urobilinogen tests were performed on 5 successive days from the beginning of the attack. Following 118 attacks, the same test was performed at intervals of 1,2 and 3 weeks. From the second to the fifteenth week, the same test was performed on an additional 1561 specimens from 227 men. The results are shown in Figure 1. On the first day of the attack, 20 per cent of the tests were positive in a dilution greater than $1: 20$, and 41 per cent were positive in a dilution greater than $1: 10$. The number of elevated concentrations steadily decreased so that by the fifth day but few were above the normal limit. From 2 to 15 weeks after attacks the values were practically identical with those obtained with the normal healthy controls.

Serum albumin, globulin and total protein: The serum albumin, globulin and total protein were determined from 1 to 26 weeks following recurrent attacks of malaria in 172 men. All values for serum albumin were within normal limits. In 3 men values above 2.7 grams per $100 \mathrm{ml}$. were obtained for the globulin, with the highest being 3.1. In only 2 men were the values for total protein below 6.0 grams per $100 \mathrm{ml}$., with the values being 5.0 and 5.8 respectively. It is evident that hyperglobulinemia and hypoproteinemia were not frequent in this group of patients.

Cholesterol: Cholesterol determinations were made on 156 fasting patients after recurrent attacks of malaria. None had a value below 150 mgm. per $100 \mathrm{ml}$. Thirteen men had values between 251 and 260,5 between 261 and 270,3 between 271 and 280 and 1 between 281 and 290 mgm. per $100 \mathrm{ml}$. This gave a total of 22 men with values above $250 \mathrm{mgm}$.

Phosphatase: The serum phosphatase was determined in 191 men following recurrent attacks of malaria. All values were below 5 Bodansky units.

\section{DISCUSSION}

Liver function in naturally-acquired malaria (1 to 3 ) has been previously studied in several countries where the disease is endemic. It has also been studied in induced malaria (4) used in the treatment of neurosyphilis. Frequently only a single test has been employed; when several tests have been used, the group studied has been quite small. Urobilinogenuria, hyperbilirubinemia, decrease in serum protein and impairment of glycogenetic function, as indicated by the galactose tolerance test, have been observed in naturallyacquired malaria (1 to 4 ). Transient disturbances in liver function have been reported-in induced malaria on a basis of moderate bromsulfalein retention, diminished hippuric acid excretion and a 
strongly-positive cephalin flocculation (4). The impairment was said by these investigators to disappear within 3 to 6 weeks after termination of the malaria.

The patients at Harmon General Hospital formed a desirable group upon which to perform liver function tests. The group was homogeneous with respect to age period, color, endemic area in which the Plasmodium vivax infection was acquired, and chronicity of disease as indicated by an average of 9 recurrent attacks in about 17 months. Clinically, these patients frequently complained of vague gastro-intestinal symptoms and were easily fatigued, even after months of convalescent care. During 308 observed attacks in these and some other patients, not included in this particular study, 32 per cent had pain in the right side, chiefly in the upper quadrant, and 12 per cent had palpable livers. All had had prolonged suppressive treatment with atabrine while overseas, as well as thorough treatment with it during recurrent attacks.

The majority of these patients were available for study for a period of 6 months. This created an opportunity to perform a large series of tests both during and after recurrent attacks of malaria and to observe whether there were any transient or possibly permanent abnormalities in liver function. During the acute attacks, with those tests which gave presumptive evidence of liver dysfunction, less than $\mathbf{5}$ per cent of the bromsulfalein tests were abnormal. With the cephalin flocculation test 82 per cent of the tests were positive with the Difco antigen and 21 per cent with the Wilson antigen. One worker (19) has recently presented evidence that either qualitative or quantitative changes in the fractions of serum protein may be responsible for cephalin flocculation. With those tests which are associated with increased hemolysis and/or disturbance in liver function; namely, the icterus index, serum bilirubin concentration and urine urobilinogen concentration, there were frequent abnormal values during the first part of the attacks with return to normal by the fifth day.

Following attacks of malaria, there was positive cephalin flocculation in 20 per cent of the tests with the Difco antigen and 5 per cent with the Wilson antigen. The results with the Wilson antigen are more in accord with the findings of 3 per cent abnormal values in both the bromsulfalein and galactose tolerance tests than are those of the Difco antigen. With the intravenous hippuric acid test, 11 per cent of the values were abnormal when compared to the control series. Evaluation of the group of tests as a whole shows that although there may be some transient disturbance during the recurrent attacks, there is at present little evidence of permanent hepatic dysfunction as a result of chronic relapsing vivax malaria treated principally by atabrine.

\section{SUMMARY}

The results obtained in the present study may be summarized as follows:

1. The results with the bromsulfalein test showed that:

(a) On the second or third days of an attack in 49 men, 4 per cent were abnormal.

(b) On the sixth or seventh days of an attack in 97 men, 1 per cent were abnormal.

(c) Following recurrent attacks in 149 men, 3 per cent were abnormal.

2. The percentages of positive cephalin flocculation tests during and after attacks of malaria with 2 different antigens were as follows:

(a) Of tests performed on the first 5 days during 42 recurrent attacks, 82 per cent were positive with the Difco antigen, and 21 per cent were positive with the Wilson antigen.

(b) Following 204 attacks of malaria, 20 per cent of these tests were positive with the Difco antigen, and 5 per cent with the Wilson antigen.

3. Galactose tolerance tests were performed on 207 men following recurrent attacks of malaria; of these 3 per cent were abnormal.

4. The intravenous hippuric acid test was performed on 56 patients following attacks of malaria. Twenty-three per cent of this group excreted less than 0.90 gram of hippuric acid in 1 hour.

5. The icterus index and serum bilirubin concentration tests were determined on the same sera both during and after attacks of malaria.

(a) At the onset of 118 attacks, 16 per cent of the values for the icterus index were greater than 8 units, and 20 per cent of those for the bilirubin concentration were greater than $0.50 \mathrm{mgm}$. per $100 \mathrm{ml}$. of serum. By the fifth day, and for the following 15 weeks, the values were approximately normal. 
(b) The degree of elevation above normal in both tests was not great, nor did elevation occur in every individual.

6. The urine urobilinogen test was performed both during and after attacks of malaria. On the first day of 176 attacks, 20 per cent of the tests were positive at a dilution greater than $1: 20$. By the fifth day but few tests showed values above normal although an occasional individual had an elevated figure for a short period of time with the rest being about normal within 2 to 15 weeks after an attack.

7. In 172 men following recurrent attacks of malaria, the albumin, globulin and total protein were normal in all but 5 men.

8. In 156 men following recurrent attacks of malaria, the serum cholesterol was essentially normal.

9. In 191 men following recurrent attacks of malaria, the phosphatase was normal.

\section{CONCLUSION}

Liver function tests in 317 patients with chronic relapsing vivax malaria treated principally by atabrine disclosed evidence of some transient disturbance during recurrent attacks but gave little or no indication of permanent hepatic dysfunction.

\section{BIBLIOGRAPHY}

1. Fairley, N. H., Liver insufficiency in malaria. Congres International de l'Insuffisance hepatique, Vichy, 1937, 1, 189.

2. Meleney, H. E., The physiological pathology of malaria. In Human Malaria. Publication of the Am. Asso. for the Advancement of Sc., Lancaster, $\mathrm{Pa}$. The Science Press Printing Company, 1941 p. 229.

3. Lall, J., and Singh, J., Urobilinuria and its importance in malaria. Indian M. Gaz., 1933, 68, 139.

4. Kopp, I., and Solomon, H. C., Liver function in therapeutic malaria. Am. J. M. Sc., 1943, 205, 90.
5. Todd, J. C., and Sanford, A. H., Clinical Diagnosis by Laboratory Methods. Rosenthal's Bromsulfalein Method. W. B. Saunders Co., Philadelphia, 1943, Ed. X, p. 428.

6. Hanger, F. M., The flocculation of cephalin-cholesterol emulsions by pathological sera. Tr. A. Am. Physicians, 1938, 53, 148.

7. Hanger, F. M., Serological differentiation of obstructive from hepatogenous jaundice by flocculation of cephalin-cholesterol emulsions. J. Clin. Invest., 1939, 18, 261.

8. Neefe, J. R., and Reinhold, J. G., Photosensitivity as a cause of falsely positive cephalin-cholesterol flocculation tests. Science, 1944, 100, 83.

9. Quick, A. J., The hippuric acid tests for liver function. In The Hemorrhagic Diseases. Chas. C. Thomas, Springfield, Ill., 1942, Ed. I, 325.

10. Thannhauser, S. J., and Andersen, E., Methodik der quantitativen Bilirubin-Bestimmung in menschlichen Serum. Uber die Ehrlich-Proschersche Reaction. Deutsches Arch. f. klin. Med., 1921, 137, 179.

11. McNee, J. W., and Keefer, C. S. The clinical value of the Van den Bergh reaction for bilirubin in blood; with notes on improvements in its technique. Brit. M. J., 1925, 2 , 52.

12. Wallace, G. B., and Diamond, J. S., The significance of urobilogen in the urine as a test for liver function. Arch. Int. Med., 1925, 35, 698.

13. Minot, A. S., and Keller, M., A modification of the Greenberg technic for the colorimetric determination of serum protein. J. Lab. and Clin. Med., 1936, 21, 743.

14. Forbes, J. C., Determination of cholesterol in blood plasma and serum. J. Lab. and Clin. Med., 1931, 16, 520 .

15. Bodansky, A., Determination of serum inorganic phosphate and serum phosphatase activity. Am. J. Clin. Path. (Tech. Supp.), 1937, 7, 51.

16. Fiske, C. H., and Subbarow, Y., The colorimetric determination of phosphorus. J. Biol. Chem., 1925, 66, 375.

17. Mateer, J. G., Baltz, J. I., Marion, D. F., and MacMillan, J. M., Liver function tests. J. A. M. A., 1943, 121, 723.

18. Scurry, M. M., and Field, H., Jr., Correlation of the intravenous hippuric acid test of liver function with body size. Am. J. M. Sc., 1943, 206, 243.

19. Hanger, F. M., Unpublished data. 